\title{
EXISTE UMA LITERATURA BELGA? LIMITES DE UM CAMPO E FRONTEIRAS POLITICAS
}

\section{IS THERE BELGIAN LITERATURE? LIMITATIONS FROM A FIELD AND POLITICAL BOUNDARIES}

Pierre Bourdieu

Estratégias e instâncias de consagração, examinadas à luz da teoria dos campos, levantam o problema da identidade cultural belga, tomada como alternativa à identificação com o modelo dominante e da alteridade.

Tudo é uma questão de uso das palavras: devemos dizer literatura belga ou literatura "belga", literatura belga de língua francesa ou literatura francesa da Bélgica? Questão em debate: existe uma literatura belga?

0 problema é de interesse quase exclusivo dos escritores de nacionalidade belga, que se dividem a esse respeito, em função da posição que ocupam no seio do campo francês: na verdade, tudo parece indicar que eles estão muito mais inclinados a defender a ideia que a literatura produzida pelos escritores belgas é parte integrante da literatura francesa, quanto mais são reconhecidos no campo francês (isto é visto, por exemplo, no debate que opôs a revista nacionalista L'Art moderne ao Groupe $d u$ lundi, revista de Charles Plisnier, Grégoire le Roy, etc.).

Tudo se passa como se todo escritor de nacionalidade belga (como todo escritor francês oriundo da província) oscilasse entre duas estratégias, portanto duas identidades literárias: uma estratégia de identificação à literatura dominante e uma estratégia de restringir-se ao mercado nacional reivindicando a identidade belga. A segunda se impõe cada vez mais à medida que declinam as chances de sucesso da primeira.

Outro índice de heteronomia: os escritores belgas dispõem de um conjunto de instituições específıcas, editores, revistas, teatros, mas eles não possuem instâncias de consagração específicas (Ghelderode, por exemplo, teve de aguardar a montagem de uma de suas peças em Paris, no Théâtre de l'Oeuvre, para ser reconhecido na Bélgica), como se os escritores e o público culto não acreditassem em suas instâncias nacionais, isto é, no 
valor de seus julgamentos. Compreende-se que, nestas condições, os escritores reconhecidos apenas pelas instâncias reconhecidas, isto é, parisienses, não manifestam nenhum interesse pela criação de um campo nacional (ou local). Compreende-se também que os debates, movimentos, etc., permanecem muito estreitamente "sob influência": a dependência está nas estruturas, mas ela está também nas mentes e é ela que, como diz um observador, "desencoraja editores, anestesia a crítica, paralisa os diretores de teatro, exila os melhores talentos".

Assim, os escritores de nacionalidade belga e francófonos são colocados diante a alternativa de identificação com o modelo dominante - que, quando alcançada, os despoja de sua identidade nacional - e de exclusão na alteridade. Alteridade puramente negativa, simplesmente menor, no caso dos valões que, dominantes (pelo menos até uma data recente) entre os escritores nacionais e dedicados a reproduzir, face aos flamengos, a oposição entre a França e a Bélgica, são dominados no campo literário francês; enquanto, forte por sua participação nas "virtudes francesas" ("musicalidade", "sensibilidade”, "delicadeza”, "senso de sutileza”), afirmam sua superioridade sobre os flamengos, "coloristas", "materialistas", "instintivos”, veem-se rejeitados, em nome de uma oposição semelhante entre a alma e o corpo, pelo mundo parisiense como pálidos imitadores provinciais ou bárbaros estrangeiros. E isto sem ter, no mesmo grau que os flamengos, eles pró- prios dominados duplamente, em relação aos valões (e aos franceses) e em relação aos holandeses, a possibilidade de se resguardarem na afırmação de uma alteridade assumida (isto explica porque, paradoxalmente, os escritores belgas mais "conhecidos" - considerados Belgas - sejam quase todos flamengos). Com efeito, a alteridade pode ser constituída positivamente, como diferença fecunda, às custas da mudança de signo que transforma a barbárie e a rudeza do provincial ou do estrangeiro em exotismo literário. É ainda a lógica do campo francês que faz os escritores flamengos e é por ela e em relação a ela que os Verhaeren, Maeterlinck, Ghelderode, etc., que são suficientemente integrados no campo francês por estarem cientes do estatuto inferior (pelo menos nessa época) do campo holandês, são constituídos e constituem-se simultaneamente - como simbolistas, por exemplo - e diferentes, mas de uma diferença literalmente reconhecida.

Essa diferença legítima não é outra coisa senão o "temperamento literário" que se inventa, por meio de um verdadeiro trabalho coletivo, na relação entre os escritores dominados e as instâncias centrais. Uma representação, simplificada até o estereótipo, da pintura flamenga, das quermesses e cenas do interior, orgias e procissões, serve de fundamento à construção de uma imagem literária da "alma flamenga”, combinação de misticismo e sensualidade; essa invenção cultural, sobre uma tradição cultural, torna-se o princípio natural, inscrito

1. Supondo que pretendem levar até o fim a estratégia de mitigar a diferença, eles apenas encontrariam, como a maior parte dos provinciais, um sotaque, e estigmatizado. Todas as contradições, e todos os dramas da identidade cultural dominada concentram-se na relação com a língua, e no conflito entre a língua central e a língua local, que está no coração de cada um e que pode assumir formas dramáticas quando ambos os usos (distinto, parisiense, vulgar, belga) se incarnam nas duas figuras de autoridade, paternal e maternal. 
no "terroir", de uma "literatura flamenga" dotada das mesmas propriedades. E essas propriedades são mais facilmente encontradas nas obras literárias que nos artistas, que, por sua vez, podem se apoiar sobre o mito do "terroir" ou inverter o signo do estigma ou da injúria para se construir um "temperamento literário" conforme a imagem literária do "temperamento regional". Deste modo, é em relação ao campo francês, às suas referências e aos seus "guias iluminados" (Victor Hugo, a quem ele via como um quase-bárbaro, e, sobretudo, Baudelaire e Mallarmé), que Verhaeren estabelece sua diferença, seu "temperamento flamengo" oriundo não do "terroir", mas da representação literária do "terroir”. 0 efeito de campo é ainda mais evidente no caso dos escritores propriamente "regionalistas", tal como Charles de Coster, grande leitor de Rabelais, e, depois dele, Lemonnier, que inventam uma literatura flamenga, próxima do povo e liberta dos refinamentos decadentes, quando o prestígio do naturalismo favorece o sucesso desta forma de realismo exótico que é concedida aos provinciais.

Assim, tudo leva a concluir que não existe, propriamente falando, um campo literário belga e, próximos ao dos provinciais, os escritores belgas de língua francesa permanecem submetidos às leis do campo literário francês. Dito isso, as fronteiras políticas, em sua arbitrariedade legal, determinam as descontinuidades na continuidade do campo de forças e a independência política, que dota os escritores e artistas das instâncias nacionais, academias, universidades, associações, revistas, teatros, jornais, etc., não é totalmente desprovida de efeitos apenas porque estas instituições oferecem um mercado protegido, onde a eficácia da concorrência, cujo campo literário é o lugar, se encontra parcialmente suspensa. ${ }^{2}$ Mas podemos nos perguntar se isso não resulta de uma defasagem estrutural entre as hierarquias no campo literário francês e as hierarquias no seio das instituições nacionais, condenadas a ser dominadas por agentes que são, ou são percebidos como, produto de uma seleção negativa, e se esta defasagem, através dos efeitos que produz (como a desconfiança em relação às instâncias nacionais de consagração), não é de natureza a reproduzir a relação de dependência simbólica da qual é produto. ${ }^{3}$

Recebido em: 24/01/2020

Aprovado em: 05/03/2020

2. Cf. por exemplo "La Belgique malgré tout", Revue de l'Université de Bruxelles, 1980, pp. 502-506.

3. A mesma análise valeria para a Suiça e Canadá de língua francesa, com as diferenças como a ausência de tradição predisposta a ser constituída como "temperamento", ou a situação de dupla dependência, em relação à Alemanha ou aos Estados Unidos e à França, que pode permitir estratégias de defesa pelo uso cruzado de uma dominação contra a outra. 
